\title{
Wildland Weeds: Paragrass, Urochloa mutica ${ }^{1}$
}

\author{
L. T. Markle, B. A. Sellers, and W. A. Overholt ${ }^{2}$
}

\section{Introduction}

When people think of Florida, one image that immediately comes to mind is water-whether the steady flow of waves on the coastal beaches or the morning mist rising from one of the state's lakes or rivers. The state's fresh waters include 7,700 lakes and ponds and 1,400 rivers and streams, covering a total of 1.5 million acres (Florida Fish and Wildlife Conservation Commission [FWC] 2011). The state's public waters are used for many purposes, including recreation, commerce, potable water, flood control, irrigation, habitat, ecotourism, and navigation. In short, water is a key component in the state's ecological and economic well-being.

At both the ecological and economic level, Florida's public waters have become progressively imperiled because of the increased presence and pressures of invasive aquatic plants. One or more exotic plant species can be found in $95 \%$ of Florida's public waters. Of the 23 exotic aquatic plants currently known to be invading the state's public waters, 11 are listed as Category I invasive plants by the Florida Exotic Pest Plant Council (FLEPPC). Invasive aquatic plants cause many negative impacts on aquatic systems, including oxygen depletion, stunted fish populations, fish kills, water flow restrictions, flooding, accelerated sedimentation, reduction in system diversity, and loss of recreation areas. Paragrass (Urochloa mutica (Forsk.) T.Q. Nguyen) (Figure
1) is a semiaquatic invasive grass that causes negative impacts to Florida's public lakes, rivers, and canals.

Paragrass (also referred to as Californiagrass) is thought to have been introduced into Florida sometime in the late 1870s (Austin 1978) as a forage plant (Godfrey and Wooten 1979). The semiaquatic grass is a native of tropical Africa, and today it is established in both hemispheres in tropical and subtropical regions as a highly palatable fodder (Handley and Ekern 1981; Vicente-Chandler et al. 1974). In the United States, paragrass has become naturalized in cultivated and ruderal areas. The grass is established in regions of poorly drained soils and along freshwater shorelines in Alabama, Florida, Hawaii, Maryland, Oregon, South Carolina, and Texas (Handley and Ekern 1981).

\section{Impacts of Paragrass}

Paragrass is listed as a Category I invasive species by FLEPPC (2011). FLEPPC defines Category I plants as those that alter native plant communities by displacing native species, changing community structures or ecological functions, or hybridizing with natives.

Presently, 11 species of Urochola occur in Florida. Of these, 9 are exotic and survive outside of cultivation (Wunderlin and Hansen 2011). Results from a Florida-based survey conducted in 2011 found paragrass in 191 public waters covering 1,154 acres (FWC 2011).

1. This document is SS-AGR-370, one of a series of the Agronomy Department, Florida Cooperative Extension Service, Institute of Food and Agricultural Sciences, University of Florida. Original publication date April 2013. Please visit the EDIS website at http://edis.ifas.ufl.edu.

2. L. T. Markle, USDA/ARS Horticultural Research Laboratory, Fort Pierce, FL; B. A. Sellers, associate professor, Agronomy Department, Range Cattle Research and Education Center, Ona, FL; and W. A. Overholt, professor, Entomology Department, Indian River Research and Education Center, Fort Pierce, FL; Florida Cooperative Extension Service, Institute of Food and Agricultural Sciences, University of Florida, Gainesville, FL 32611.

The use of trade names in this publication is solely for the purpose of providing specific information. UF/IFAS does not guarantee or warranty the products named, and references to them in this publication do not signify our approval to the exclusion of other products of suitable composition. 


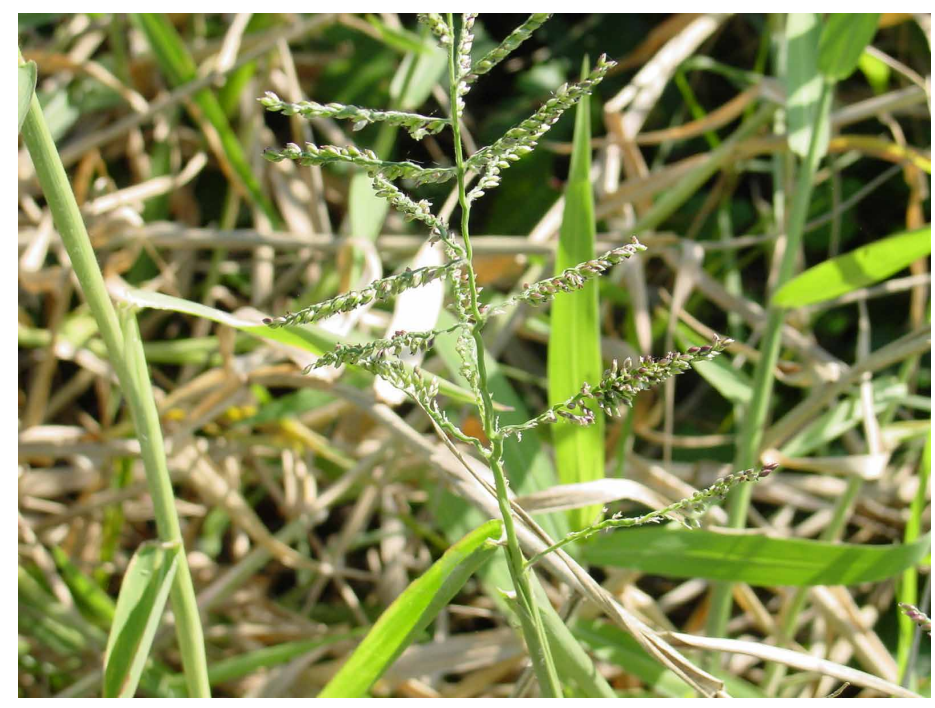

Figure 1. Panicle-like inflorescence of Urochola mutica composed of false spikes.

Credits: Jeffery Hutchinson, University of Florida Center for Aquatic and Invasive Plants

Paragrass is an extremely resilient species that can endure long periods of drought and prolonged flooding or water logging. It can tolerate precipitation extremes of 34-161 inches per year, and survives in regions with annual mean temperatures ranging from $67^{\circ} \mathrm{F}$ to $81^{\circ} \mathrm{F}$ (Duke 1983). The plant also has a fast growth rate and produces allelopathic chemical inhibitors (Chang-Hung 1977) that minimize the success of the germination and growth of other plants. All of these factors combine to make paragrass an extremely aggressive competitor that can displace many shoreline emergent plants and plants in cultivated or disturbed sites associated with moist soil. Paragrass becomes readily established in wet soils along shorelines where it can form large monocultures.

Paragrass has two methods of reproduction (Figure 2). The most common method of reproduction is by vegetative means (asexual reproduction) from stem joints on prostrate stolons that produce roots and erect stems. The grass also reproduces from seed, although a recent study suggested that seed viability may be very low. Seed production is advantageous for the plant. Seeds provide a means of dispersing the grass along banks and shorelines during high water periods, and provide a source of continued survival during low water periods.

\section{UF/IFAS Assessment}

The UF/IFAS assessment of nonnative plants in Florida's natural areas (http://plants.ifas.ufl.edu/assessment/pdfs/ results.pdf) provides a mechanism to ensure all UF/ IFAS Extension publications conform in their description and classification of invasive plants. Understanding the

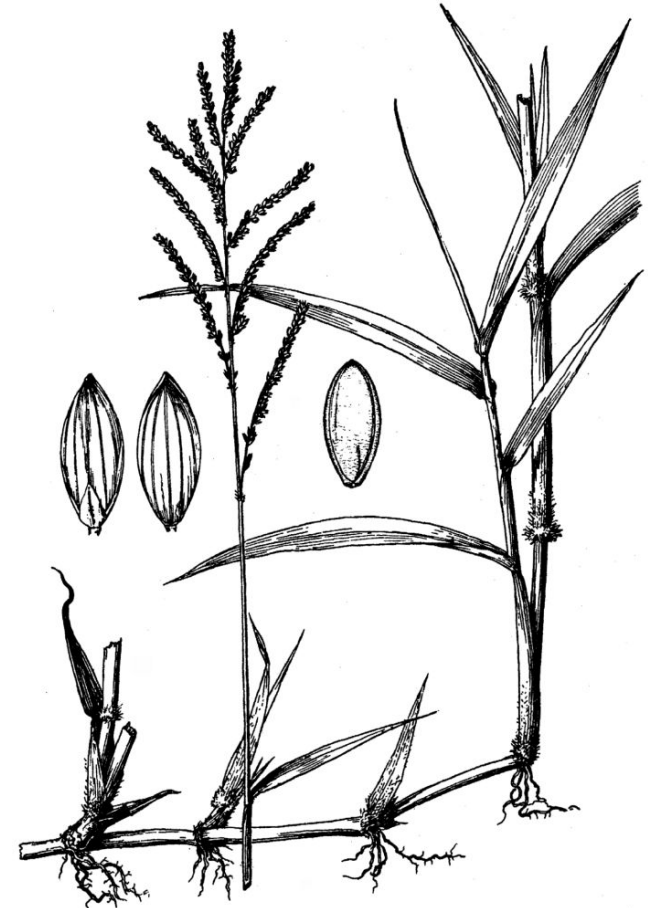

Figure 2. Artist's drawing of seeds, inflorescence, stem, leaves, and stolon of paragrass.

Credits: USDA-NRCS Plants Database

conclusions of the assessment and how UF/IFAS arrived at those conclusions can help prevent or reduce the likelihood of problem species further invading natural areas. The October 2011 revision of the UF/IFAS assessment listed paragrass as a nonnative invasive plant species in Florida and concluded that this species is invasive and not recommended for use by IFAS faculty in the northern, central, and southern zone counties of the state. Based on the IFAS species assessment, paragrass has high ecological impacts, high potential for expansion, and high difficulty of management in the northern, central, and southern zones of the state.

\section{Identification of Paragrass}

Paragrass is a perennial species found along shorelines and in perpetually wet areas (e.g., drainage systems, bogs and marshes, irrigation canals, etc.). When present, the panicle-like inflorescence of paragrass provides the surest method of identification (Figure 1). In Florida, paragrass flowers from September to December (Hall 1978). The primary axis of the inflorescence can range from 10 to 20 $\mathrm{cm}$ in length (Napper 1965) and is composed of 8-20 false spikes alternately arranged on the axis (Duke 1983). False spikes are composed of numerous paired spikelets arranged in several irregular rows. In Poaceae, by definition, spikelets are the smallest aggregation of florets (flowers) and associated glumes (Wunderlin and Hansen 2011). Spikelets are subsessile (supported by a short pedicel) and range from 
3 to $3.5 \mathrm{~mm}$ in length (Napper 1965). Spikelets possess a slight purple tint (Langeland and Craddock Burks 1998).

If inflorescence is lacking or further species verification is desired, the plant has several other identifying characteristics. One primary indicator is the presence of dense regions of hair on several parts of the plant (Figure 3). The leaf nodes (points on the axis where leaves arise) of paragrass are swollen in appearance and are accompanied by long white, shaggy hairs (Duke 1983). Fine, short hairs are present on the basal surface of leaf blades. Leaf blades are linear to linear-lanceolate, acuminate, and are $10-30 \mathrm{~cm}$ in length and between $1.25-1.9 \mathrm{~cm}$ in width. Leaf sheaths are loose and overlapping with short, stiff hairs, particularly at sheath/ligule junctions. Stems on mature plants sprawl outward and recline on the ground before finally ascending upward, reaching a length of 1-3.6 m.
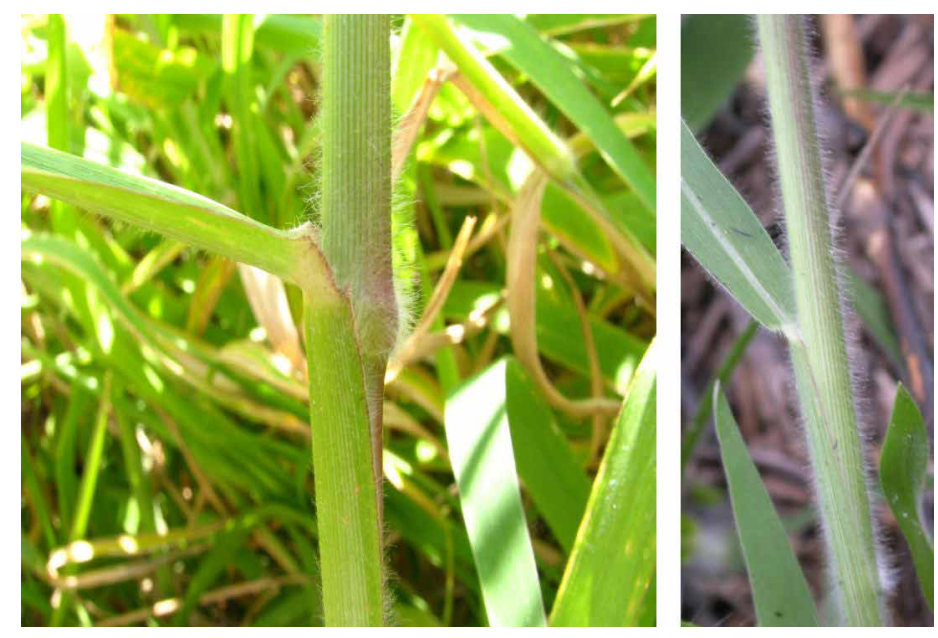

Figure 3. Left: Short, stiff hairs on the stem (note the swollen appearance of the nodes and the long, white, shaggy hairs present at those points). Right: Numerous stiff hairs on and around the sheath (note that even newer portions of the stem contain hairs).

Credits: Left: W. A. Overholt, Right: Jeffery Hutchinson, University of Florida Center for Aquatic and Invasive Plants

\section{What Can You Do to Control Paragrass?}

Before attempting to control a suspected invasive plant, you must first verify its identification. Grasses can be challenging to identify, even for professional taxonomists and botanists. Species verification can be obtained from your local UF/IFAS Extension office (you can find your UF/ IFAS Extension office here: http://solutionsforyourlife.ufl. edu/map/).

Cultural practices, including burning or roller-chopping followed by flooding so that no plant propagules protrude from the water surface, have been shown to provide greater than $90 \%$ control of paragrass in highly infested areas.
The burning or roller-chopping method has been shown to be successful in areas where flooding can be controlled. Mechanical control of small infestations of paragrass can be achieved with repeat tillage, but regrowth from paragrass stolons should be expected.

Herbicides successful in controlling spread of paragrass in infested areas include glyphosate and imazapyr (Chaudhari et al. 2012a). Common glyphosate herbicides labeled for use in water bodies include Rodeo, AquaMaster, AquaNeat, Eagre, AquaPro, and Glypro. Common imazapyr herbicides labeled for use in lakes, ponds, ditches, canals, and reservoirs include Habitat and Polaris. Application rates for each herbicide differ, and rates must be determined based on label rates for a given type of water body and the total area sprayed. Always read the label.

Integrating chemical and cultural practices can be effective. If a paragrass stand has not been burned for many years, it will be necessary to burn the area prior to any type of treatment plan. If the area can be flooded, flooding should occur immediately following the burn; this has resulted in greater than $90 \%$ control in previous studies (Chaudhari et al. 2012b). If controlled flooding cannot be implemented, treat with either glyphosate or imazapyr from May to August. If imazapyr is used for paragrass control, remember that it has residual activity. However, if applied to paragrass in standing water, the half-life of imazapyr is greatly reduced, and native species establishment will be similar to when glyphosate is used. Also, burning paragrass stands at least six weeks after herbicide application will remove paragrass biomass, allowing native species establishment. If flooding does not occur, retreatment with herbicides may be required.

Regardless of control method, scout the area of concern and treat any escapes. Paragrass stolons can grow quickly.

Biological control of paragrass is limited at this time. The sterile, triploid grass carp (Ctenopharyngodon idella) has had some success for the biological control of various invasive aquatic weeds (submersed plants and small floating plants) and filamentous algae. The grass carp will eat paragrass, but research has shown the fish only partially controls the invasive grass (Thayer et al. 2003). No research has been conducted to find insect biological control agents of paragrass. 


\section{References}

Austin, D. F. 1978. "Exotic Plants and Their Effects in Southeastern Florida." Environ. Conserv. 5 (1): 25-34.

Chang-Hung, C. 1977. "Phytotoxic Substances in Twelve Subtropical Grasses I. Additional Evidences of Phytotoxicity in the Aqueous Fractions of Grass Extracts." Bot. Bull. Acad. Sinica 18 (2): 131-141.

Chaudhari, S., B. A. Sellers, S. V. Rockwood, J. A. Ferrell, G. E. MacDonald, and K. E. Kenworthy. 2012a. "Integrating Chemical and Cultural Practices to Control Para Grass (Urochloa mutica)." J. Aquat. Plant. Manage. 50: 39-45.

Chaudhari, S., B. A. Sellers, S. V. Rockwood, J. A. Ferrell, G. E. MacDonald, and K. E. Kenworthy. 2012b. "Non-Chemical Methods for Paragrass (Urochloa mutica) Control." Inv. Plant Sci. Manag. 5 (1): 20-26.

Duke, J. A. 1983. "Handbook of Energy Crops.” Unpublished report. Purdue University Center for New Crops and Plants Products. Accessed April 2013. http://www.hort. purdue.edu/newcrop/duke_energy/Brachiaria_mutica. html.

Florida Fish and Wildlife Conservation Commission (FWC). 2011. Invasive Plant Management Section Annual Aquatic Plant Survey, 2011. Accessed April 2013. http:// myfwc.com/wildlifehabitats/invasive-plants/aquatic-plant/.

Godfrey, R. K., and J. W. Wooten. 1979. Aquatic and Wetland Species of the Southeastern United States: Monocotyledons. Athens: University of Georgia Press.

Hall, D. W. 1978. "Poaceae: The Grasses of Florida." PhD diss., University of Florida, Gainesville, FL.

Handley, L. L., and P. C. Ekern. 1981. "Irrigation of California Grass with Domestic Sewage Effluent: Water and Nitrogen Budgets and Crop Productivity." Unpublished report. University of Hawaii at Manda.

Langeland, K. A., and K. Craddock Burks. 1998. Identification and Biology of Non-native Plants in Florida's Natural Areas. SP257. Gainesville: University of Florida Institute of Food and Agricultural Sciences.

Napper, D. M. 1965. “Grasses of Tanganyika.” Bull. No. 18. Tanzania: Ministry of Agriculture, Forests and Wildlife.

Thayer, D. D., K. A. Langeland, W. T. Haller, and J. C. Joyce. 2003. Weed Control in Florida Ponds. CIR 707. Gainesville:
University of Florida Institute of Food and Agricultural Sciences.

Vicente-Chandler, J., F. Abruna, R. Caro-Costas, J. Figarella, S. Silva, and R. W. Pearson. 1974. "Intensive Grassland Management in Humid Tropics of Puerto Rico." Unpublished report. Rio Pedras: University of Puerto Rico Agricultural Experiment Station.

Wunderlin, R. P., and B. F. Hansen. 2011. Guide to the Vascular Plants of Florida, $3^{\text {rd }}$ edition. Gainesville: University Press of Florida. 